C O L A B O R A Ç Ã O E S P E C I A L

\title{
CONTRA O LIBERALISMO E O COMUNISMO: UMA DEMOCRACIA AUTORITÁRIA
}

Against liberalism and communism: an authoritarian democracy

Contra el liberalismo y el comunismo: una democracia autoritaria

http://dx.doi.org/10.1590/S2178-14942020000300003

'Universidade Federal de São Carlos - São Carlos (SP), Brasil.

*Professora aposentada da Universidade Federal de São Carlos.

(D) https://orcid.org/0000-0003-0067-9052

Artigo recebido em $1^{\circ}$ de maio de 2020 e aprovado para publicação em 03 de julho de 2020. 


\title{
RESUMo
}

Tratamos dos primeiros 15 anos do governo Vargas, de sua legislação trabalhista e de sua atitude diante da valorização do trabalho e do trabalhador. A partir da análise das lutas do movimento operário, da pesquisa em jornais, programas e documentos de Vargas, verificam-se seus objetivos: o de elaborar uma legislação trabalhista, que contempla e submete os trabalhadores; o de forçar os empresários a respeitarem tal legislação, tendo como objetivo obter paz social, a verdadeira democracia, que só poderia ser mantida pondo fim ao liberalismo e governando por meio do centralismo autoritário, a que chamava de democracia autoritária.

PALAVRAS-CHAVE: o primeiro governo Vargas; legislação trabalhista; lutas operárias; liberalismo; autoritarismo.

\begin{abstract}
We deal with the first 15 years of the Vargas government, its labor legislation and attitude toward the valorization of work and workers. From the analysis of the struggles of the workers' movement, from the research in their newspapers and programs and from Vargas documents, its objectives are verified: that of drafting labor legislation, which contemplates and submits workers; to force businessmen to respect such legislation, aims to achieve social peace, true democracy, which could only be maintained by putting an end to liberalism and governing through authoritarian centralism, which he called authoritarian democracy.
\end{abstract}

KEYWORDS: the first Vargas government; labor legislation; workers' struggles; liberalism; authoritarianism.

\section{RESUMEN}

Nos ocupamos de los primeros 15 años del gobierno Vargas, de su legislación laboral y de su actitud hacia la valorización del trabajo y del trabajador. A partir del análisis de las luchas del movimiento obrero, del examen de su prensa, de sus documentos programáticos y de documentos de Vargas, vemos que sus objetivos consisten en: redactar la legislación laboral, que contempla y presenta a los trabajadores; obligar a los empresarios a respetar dicha legislación, con la finalidad de imponer la paz social, "la verdadera democracia", que solo podría mantenerse poniendo fin al liberalismo y gobernando a través del centralismo autoritario, a lo que denominaba democracia autoritaria.

PALABRAS CLAVE: el primero gobierno Vargas; legislación laboral; luchas obreras; liberalismo; autoritarismo. 


\section{INTRODUÇÃO}

W umerosos e importantes trabalhos já foram escritos sobre a chamada "Era Vargas". Carneiro, entre muitos outros. Minha contribuição para a discussão sobre o tema — sempre inesgotável - é enfocar o que considero aparentes contradições do governo Getúlio Vargas. Por um lado, foi um governo que estabeleceu uma ditadura durante quase oito anos. Embora não pense que a ditadura já estivesse implícita no movimento que em outubro de 1930 levou Vargas ao poder, o autoritarismo sempre esteve presente no governo Vargas - como de resto em todos os governos do país — - cuja implantação deveu-se bastante ao apoio dos tenentes, com seu ideário autoritário e elitista. A instauração do Estado Novo deu-se graças ao apoio militar, agora do alto oficialato, este não só autoritário e elitista como simpatizante do nazifascismo. Por outro lado, o Estado Novo foi uma ditadura popular, com o apoio da maior parte do movimento operário e sindical (que Getúlio organizou, fortaleceu e subjugou), de boa parte do funcionalismo público (que o governo organizou) e com o respaldo das Forças Armadas.

A proposta getulista era a de construção de uma grande nação, com independência econômica e paz social. Do ponto de vista econômico, poder-se-ia ainda pensar em um capitalismo autárquico, uma vez que o imperialismo ainda não dominara completamente a produção, mas esta é outra discussão. Do ponto de vista político e social, muito mais voltado para o social do que para o político, prometia ser uma "sociedade democrática", para Vargas sinônimo de harmonia entre as classes, que só poderia ser conquistada por meio de uma centralização autoritária. Só o autoritarismo poderia permitir a necessária centralização para a conquista de uma sociedade supostamente democrática, quer dizer, que atendesse, controlada pelo governo, às reivindicações de todas as classes.

0 pensamento norteador do governo Vargas foi uma mistura, ou melhor, uma convergência entre o positivismo, autoritário, e as posições também autoritárias de ideólogos, principalmente Oliveira Vianna, que pregavam e justificavam uma "ditadura democrática".

Para fazer a nação crescer e destacar-se no mundo seria preciso proteger todas as classes, com maior atenção aos até então desatendidos: os trabalhadores. Para isso, seria preciso acabar com a "anarquia" de reivindicações de grupos; atender a todos, acabando com oposições de classe; seria preciso disciplina e obediência: "Os povos só progridem e expandem-se quando os indivíduos (...) se conduzem no sentido, não da afirmação de si mesmos, mas da abdicação de si mesmos; abdicação que se expressa no espírito de disciplina e no dever de obediência" (Vianna, 1952: 17, grifos do original). A paz social, absolutamente necessária, só poderia ser garantida, portanto, pelo governo autoritário, porque, sem tal autoridade cen- 
tralizadora, a anarquia imperaria. Mas essa autoridade seria para construir a "verdadeira democracia" que só poderia ser mantida por ela. Para Vargas e seus ideólogos, a democracia não era o governo do povo, e sim um governo para o povo, na construção de uma paz social só conseguida e mantida pela ditadura.

Seria preciso ajudar a classe operária a viver com dignidade, mas colocada em seu devido lugar, o de membros inferiores da sociedade (segundo o positivismo). E seria preciso ajudar os patrões a entenderem, pela obrigação de cumprir a legislação trabalhista, que só fazendo concessões à classe operária seria possível, perdendo poucos anéis, manter todos os dedos. Tentava-se invisibilizar a real contradição entre democracia e autoritarismo, ou ditadura, o que expressava exemplarmente os limites do liberalismo brasileiro. 0 autoritarismo sempre existiu na sociedade brasileira, revestido agora de maior sagacidade na conquista de apoio popular. Por isso a acolhida das esdrúxulas formulações de Oliveira Vianna sobre a importância de uma "democracia autoritária".

0 período dito liberal da Primeira República só foi liberal para as classes dominantes e parte das camadas médias urbanas, então em crescimento e quase sempre ligada por laços familiares aos donos do poder. 0 movimento de 1930 pretendeu reformular toda a política brasileira e dar atenção aos trabalhadores, mas, fosse no período revolucionário - o mais liberal deles - ou constitucional ou ditatorial, os limites foram os mesmos: conter a classe operária, ou pela força ou pela cooptação. Sem querer igualar liberalismo e ditadura, o que quero salientar é que: um ou outro tipo de governo só poderá ser entendido a partir de uma análise de classe.

\section{TENTATIVAS DE ORGANIZAÇÃO DA CLASSE OPERÁRIA NA PRIMEIRA REPÚBLICA}

classe operária, desde que surgiu, sempre lutou pelos seus direitos, e o número de gre-
ves em São Paulo confirma isso (Simão, 1966). As reivindicações eram principalmente de redução de horas de trabalho, higiene nos locais de trabalho e nas moradias, aumentos salariais, proibição de trabalho de menores e redução da jornada para crianças e mulheres. Se as reivindicações eram as mesmas, as perspectivas de organização e os métodos de luta diferiam conforme os grupos que as lideravam. 0 objetivo de mencionar aqui as lutas e organizações operárias antes de 1930 é o de embasar a discussão das atitudes dos trabalhadores, mais tarde, em relação à legislação trabalhista de Vargas, mostrando as dificuldades de terem ganho nessas lutas, maiores ainda para se organizarem e principalmente para conseguirem a unidade da classe. 


\section{OS SOCIALISTAS}

Entre os propagandistas de ideias socialistas, já no final do século XIX, início do século CXX, havia pessoas oriundas da classe operária, como os gráficos José Veiga e França e Silva, e o anarquista Mariano Garcia, operário da indústria de cigarros e depois jornalista, mas a maior parte destes pioneiros pertencia às camadas médias urbanas, como os professores Vicente de Souza e Eugênio Borba, o jornalista Gustavo de Lacerda, o advogado Evaristo de Moraes e os médicos Estevam Estrela, Silvério Fontes, Sóter de Araújo e Carlos Escobar. Estes três últimos formaram em Santos, em 1889, um Círculo Socialista que, para Astrojildo Pereira, teria sido a mais antiga organização socialista de que se tem notícias no Brasil (Pereira, 1962: 404). A 12 de dezembro do mesmo ano foi escrito o manifesto do círculo, divulgado pela imprensa em 1902 (Partido Socialista Brasileiro). Esses pioneiros da difusão do socialismo no Brasil estavam imbuídos das ideias positivistas e evolucionistas em voga à época.

Evaristo de Moraes assinala, em 1890, os surgimentos dos primeiros partidos socialistas no Distrito Federal, em São Paulo e em Porto Alegre.

Em 1895, o Círculo Socialista de Santos transformou-se em Centro Socialista de Santos, que editou, por mais de um ano, um jornal quinzenal, A questão social, cujo primeiro número apareceu a 15 de setembro daquele ano. Sem nenhuma dúvida, esse Centro Socialista teve importância na história da organização da classe operária e na difusão de ideias socialistas. 0 pensador francês Benoit-Malon, a grande influência ideológica no centro, dificilmente poderia ser chamado de marxista.

A maioria dos partidos socialistas criados à época apelava com frequência para a caridade, a bondade e a justiça que, segundo eles, os patrões deveriam demonstrar para com os proletários, os quais, por sua vez, deveriam ter espírito de tolerância e evitar "abalos subversivos".

0 que caracterizou os socialistas e os diferenciava dos anarquistas foi a ideia de um socialismo conquistado na legalidade, daí a importância que davam às lutas eleitorais, aos apelos à compreensão e à caridade dos industriais para com os trabalhadores e, muitas vezes, à afirmação de não serem revolucionários. Ao constatar o reformismo dos primeiros socialistas, é preciso entender a dificuldade, sem base de classe, de consolidar uma organização revolucionária. Antônio Piccarolo, um dos fundadores do jornal socialista Avanti!, fala sobre as primeiras tentativas de socialismo no Brasil:

Indivíduos vindos da Europa, especialmente da Itália, trazendo consigo a convicção e o ideal socialista, procuraram transplantá-los no Brasil, fundando um partido socialista brasileiro. Parece perfeitamente ocioso dizer que estas tentativas encontraram sorte por completo negativa, tendo a semente caído em terreno impreparado e contrário a todo desenvolvimento socialista. (Piccarolo, 1932: 55-57) 


\section{OS ANARQUISTAS: NEM DEUS NEM MESTRE}

G igi Damiani, anarquista italiano e com grande atuação no Brasil, definiu o anarquismo como "a concepção de um futuro para a Humanidade que exclua todo princípio de autoridade, de domínio e de exploração do homem pelo homem" (Damiani apud Leuenroth, 1963: 21).

Um ponto importante do anarquismo foi o repúdio ao parlamento e à ação eleitoral, uma vez que desprezavam toda e qualquer ação política nos marcos da sociedade capitalista. É importante frisar que os anarquistas não desprezavam a ação política, mas a entendiam como ação direta - greves, manifestações, boicotes - e nunca pela atuação partidária e eleitoral, que consideravam traição, por reconhecer e assumir os métodos da burguesia.

Nos primeiros anos do século XX, os anarquistas tiveram maior influência no movimento operário, sendo responsáveis por intensa propaganda de luta em seu meio, por intermédio de inúmeros jornais e da organização dos primeiros congressos operários. Lutavam basicamente pelas mesmas reivindicações lançadas pelos primeiros grupos socialistas: jornada de oito horas, aumento salarial, abolição de multas, regulamentação do trabalho de mulheres e crianças, férias remuneradas, higiene nos locais de trabalho, moradias decentes etc. Não admitiam, como vimos, ao contrário dos socialistas (e, mais tarde, dos comunistas), qualquer organização de caráter político. Os anarquistas — os sindicalistas revolucionários, o grupo mais atuante no Brasil — consideravam que o sindicato não tinha caráter político, e sim reivindicativo, sendo por isso a única forma de organização que aceitavam porque somente essa associação poderia unir todos os trabalhadores em torno de seus interesse, sem divisões políticas e ideológicas e sem autoridades e hierarquias de mando.

Nos primeiros anos do século XX, os anarquistas tiveram papel fundamental na organização do movimento operário, não só pela propaganda em seu meio, por meio de inúmeros jornais, como também pela organização de associações de resistência, pelo auxílio mútuo e pela realização de congressos operários.

Foi imensa a contribuição de anarquistas portugueses, espanhóis e italianos no Brasil, dentre os quais destaca-se Neno Vasco, uma das figuras libertárias de maior importância, aqui e em Portugal, com grande atuação na imprensa anarquista, e teórico do sindicalismo revolucionário. Chegou ao Brasil em 1901 e foi diretor do jornal 0 amigo do povo, que começou a circular em 1902 na capital paulista. Logo a seguir lançou a revista Aurora. Escreveu nas páginas do jornal $A$ voz do trabalhador, onde discutiu as relações entre anarquismo e sindicalismo. De volta a Portugal, em 1911, manteve correspondência com os jornais anarquistas 
brasileiros. Seu principal livro foi A concepção anarquista do sindicalismo, publicado em 1923 e reeditado em 1984. Diz ele:

0 que no sindicalismo é essencial é a organização e a ação de classe do proletariado, é o movimento sindical. Os operários, não porque têm conscientemente este ou aquele ideal quanto à sociedade futura, mas porque são assalariados e precisam de lutar contra os patrões, agrupam-se em sindicatos (sociedades de resistência era muito mais apropriado), fora de qualquer partido. (... dos) meios de ação direta são partidários todos os operários, sejam quais forem as suas ideias políticas, sociais ou mesmo religiosas; e portanto todos se podem e devem reunir nos sindicatos para o exercício dessa ação, fazendo cada um, cá fora, se quiser, parte desse ou daquele partido político ou seita. (Vasco, 1984: 91, grifos do original)

Os anarquistas foram responsáveis por inúmeras greves e manifestações operárias, e, se estavam longe de representar a maioria da classe, foram, sem dúvida, a parte mais atuante dela. Por isso mesmo a perseguição que sofreram desde o início. 0 governo — os patrões os considerava estrangeiros malvados que traziam para cá ideias estranhas à boa índole dos brasileiros. Não havia nenhuma base para considerar as lutas operárias como exóticas, mas era essa a propaganda que se fazia.

É preciso assinalar a dificuldade de se tornar vanguarda política de uma classe que começava a se formar, sem qualquer experiência de convivência social democrática ou de organização, e que sofria uma repressão inacreditavelmente brutal: salários miseráveis, péssimas condições de trabalho, a situação de crianças subnutridas e que praticamente dormiam nas fábricas, bem como jornada de trabalho abusiva, prisões, espancamentos, deportações e assassinatos. É preciso assinalar também as dificuldades de se constituir em um grupo político importante, cujas lutas contribuíssem para a construção de uma consciência proletária. Com sua presença e atuação, conseguiram todas as conquistas que obteve a classe operária na Primeira República - poucas conquistas materiais, mas principalmente a luta pela construção da dignidade da classe.

\section{OS COMUNISTAS}

$\mathrm{O}$ s fundadores do Partido Comunista do Brasil (PCB) vieram todos do sindicalismo revolucionário, influenciados pela Revolução de Outubro na Rússia e convencidos de que uma forte organização política era indispensável para a concretização não só da revolução socialista, mas também para garantir conquistas para os operários. Afastaram-se do anarquismo pela aceitação da necessidade de um partido político e na admissão de autoridades que comandassem e coordenassem não só a vida partidária, mas a organização da futura sociedade 
socialista. Por outro lado, sem o reformismo socialista, que buscava fundamentalmente vias legais para a chegada ao poder, os comunistas admitiam a participação nas eleições.

O PCB foi fundado em março de 1922. Esse recém-fundado partido tinha pressa em filiar-se à Internacional Comunista (IC), o que Ihe daria a força e o prestígio de que carecia nacionalmente. Esse empenho em ser reconhecido pela organização internacional refletiu-se em sua imprensa, como fica explicitado nas publicações da revista Movimento Comunista (Partido Comunista do Brasil, 1922: 1). A recém-nascida imprensa comunista tratava muito pouco dos assuntos políticos nacionais e a grande maioria dos artigos era de enaltecimento da União das Repúblicas Socialistas Soviéticas (URSS) e de reproduções de artigos de comunistas russos.

No que diz respeito à Revolução de 1930, o PCB lavou as mãos, dizendo que não tomava partido em uma luta que só dizia respeito aos dois imperialismos: o inglês, que representaria os interesses agroexportadores, e o norte-americano, representante dos interesses industriais.

0 trabalho dos comunistas para influir nos meios operários foi intenso, mas sempre muito reprimido. Lutaram pela melhoria de vida da classe operária: os socialistas, pela via eleitoral e pela organização de partidos políticos da classe; os anarquistas, batalhando pelos mesmos direitos a partir da organização sindical e pela ação direta; os comunistas, que, com o mesmo programa, aceitavam as duas formas de luta. Os patrões não respeitaram parte considerável do pouco que a classe conquistou, por meio de movimentos grevistas.

\section{LUTAS DE CLASSE NA PRIMEIRA REPÚBLICA}

1 o Congresso Operário de 1906 — " "manifestou-se uma forte corrente favorável à forali de maneira irredutível, com o seu visceral preconceito 'antipolitico'". (Pereira, 1976: 34)

Apesar de o congresso não ter sido principalmente de anarquistas, foram as posições destes que predominaram.

As péssimas condições de vida e trabalho dos operários, seus salários miseráveis, um passado cuja única tradição de trabalho era a escravidão, grande contingente de mulheres e crianças nas fábricas têxteis, a falta de qualquer histórico de organização e a brutal repressão que sofriam, por um lado, assustavam a classe, cuja maioria arriscava o emprego e convivia com a ameaça de expulsão do país, de prisão e, algumas vezes, de assassinato. Basta lembrar a Lei Adolfo Gordo, que determinou a expulsão, em 1907, de mais de 100 trabalhadores estrangeiros grevistas, número que aumentou muito entre 1908 e 1921. Em 1923, o mesmo senador Adolfo Gordo reviveria a mesma lei, chamada então de "Lei Infame" ou "Lei 
Celerada". Houve também a internação na Clevelândia, para onde Artur Bernardes enviava seus opositores, a grande maioria trabalhadores grevistas, principalmente anarquistas. Poucos voltaram vivos de lá (Samis, 2002).

Os debates parlamentares sobre direitos trabalhistas mostram o pensamento dos industriais: nenhum direito para os operários, que deveriam — eles e suas reivindicações — ser tratados como casos de polícia. Quem pesquisou a ideologia de nossos industriais de 1919 a 1945 foi Marisa Saenz Leme.

Apesar de terem participado da Conferência de Paz de Genebra, em 1919, e terem aceito alguns de seus princípios sobre a questão social, tal aprovação dos representantes brasileiros em relação a esses direitos foi apenas formal (Leme, 1978: 103-104).

As poucas leis trabalhistas aprovadas na Primeira República não foram cumpridas pelos patrões. 0 grande medo deles era que fosse tornado realidade o projeto do Departamento Nacional do Trabalho, pois com ele os operários poderiam ter algum direito, pelo menos 0 de fiscalizar o cumprimento das leis estabelecidas. "Para os empresários a mediação entre patrões e operários deveria continuar a cargo do Chefe de polícia, o que Ihes permitia maior controle sobre as relações de trabalho" (Leme, 1978: 133, grifo da autora). Nada melhor para mostrar como eram considerados o trabalho e os trabalhadores na Primeira República — um caso de polícia.

A reprodução das discussões sobre a Lei de Férias, proposta em 1926, não deixa dúvidas sobre o dito acima. Como sempre, o argumento era o de que qualquer benefício trabaIhista desestruturaria a indústria (da mesma forma que o final da escravidão seria a derrocada econômica do país.). Entre inúmeros argumentos estapafúrdios, dizia-se que o operariado não necessitava de férias e que a execução da lei teria como consequência a sua desorganização moral e social. Tais afirmações decorrem das concepções que os industriais adotavam quanto ao caráter do trabalho proletário, que, por ser de natureza braçal, era visto como de qualidade inferior. 0 empregado do escritório era um intelectual que trabalhava com o cérebro. Já o operário era um trabalhador braçal cujo cérebro não gastava energias (Leme, 1978: 117-118).

Diziam os patrões que seria ilógico que o cerebral fosse equiparado, na lei, ao não cerebral: "Os lazeres, os ócios, representam um perigo eminente para o homem afeito ao trabalho, e nos lazeres ele encontra seduções extremamente perigosas, se não tiver elevação moral para dominar os instintos subalternos que dormem em todo ser humano" (apud Leme, 1978: 119).

Que fará um trabalhador braçal durante quinze dias de ócio? (...) tendo tomado férias (...) compelido pela lei? (...) Ele não tem o culto do lar (...) e procurará matar suas longas horas de 
inanição na rua (...) 0 proletariado é, pois, um elemento da coletividade que as férias estragarão. (apud Leme, 1978: 120)

E por aí seguem seus argumentos de que, apesar de absurdos e de todas as lutas operárias, foram vitoriosos e os operários, demitidos, encarcerados ou expulsos do país.

Além da luta econômica pelas suas necessidades básicas, os trabalhadores exigiam a valorização do trabalho e o reconhecimento de sua dignidade profissional e humana. E foi a legislação trabalhista, com o reconhecimento formal dos direitos do trabalhador e a dignificação do trabalho, que levou ao apoio popular ao governo Vargas.

\section{UMA DEMOCRACIA AUTORITÁRIA PARA LEVAR EM CONTA O SOCIAL E VALORIZAR O TRABALHO}

leitura da obra de Oliveira Vianna deixa claros seu elitismo e suas ideias autoritárias. Em
seus escritos políticos, critica acerbamente o liberalismo, e o faz a favor do autoritarismo. Agora bem, a meu ver, as críticas que faz ao liberalismo da Primeira República, embora tenham base, são demagógicas e falsas, porque as soluções propostas para superá-las não o são. 0 liberalismo da Primeira República era um liberalismo para as classes dominantes, enquanto os direitos dos trabalhadores eram caso de polícia. A proposta de Oliveira Vianna de um caminho supostamente alternativo não era propriamente uma terceira via, pois defendia o sistema capitalista, mas um capitalismo administrado, que garantiria a paz social e, portanto, segundo ele, a verdadeira democracia.

Oliveira Vianna dizia que o liberalismo não correspondia às necessidades de toda a nação e o criticava desde suas origens, desde os enciclopedistas, vendo na Revolução Francesa a mãe de todos os seus males (Vianna, 1952: 15).

Para organizar uma nação que pudesse ser realmente grandiosa, seria preciso centralismo e disciplina, e um dos nossos maiores problemas era o fato de que os industriais brasileiros, em seu liberalismo individualista, não estavam preparados para isso (Vianna, 1952: 73).

As ideias de um importante ideólogo do primeiro período varguista tinham inúmeros pontos de convergência com as posições autoritárias do positivismo com as quais o gaúcho Vargas comungava, admirador que era das ideias autoritárias de Júlio de Castilhos. Era preciso acolher todas as classes e camadas da sociedade, evidentemente de diferentes maneiras: dando os privilégios aos cérebros da sociedade — os industriais e os intelectuais — , mas protegendo os membros dela, seus braços e pernas, os trabalhadores. 0 que Vargas preconizava era a paz social, a harmonia entre as classes, que deveria ser gerida pelo governo, mesmo que descontentando, por vezes, as classes dominantes e cooptando ou reprimindo com brutalida- 
de os subalternos que não se submetessem às benesses do "Pai dos Pobres". Seria impossível organizar sem autoritarismo o que seria a verdadeira democracia. Para Vargas, a democracia não era o governo do povo, mas para um povo domesticado e só poderia ser "dada" se controlada por intermédio do autoritarismo. Daí o aberrante conceito de "ditadura democrática". Queria fazer com que a classe operária vivesse com dignidade, mas colocada em seu lugar, subalterno, na sociedade. Longe se estava de abandonar a ideia de dominação de classe, mas tratava-se de impor tal dominação de forma a evitar qualquer descontentamento maior dos trabalhadores. Era preciso evitar a todo custo movimentos revolucionários - e a Revolução Russa e a IC mostravam que o perigo era real.

\section{OS GANHOS MATERIAIS}

D epois de intensas lutas na Primeira República, poucas com sucesso, os operários começaram, depois de 1930, a ter algumas garantias, dadas pelo governo, por meio da legislação trabalhista. Os anos de 1931 ao Estado Novo, em 1937, apesar de representarem alguns ganhos, foram mais de gestação das incipientes medidas em prol dos trabalhadores. Como Marisa Saenz Leme assegura, a elaboração das leis trabalhistas deu-se entre 1930 e 1934, mas a ênfase nelas só ocorreu no Estado Novo, como a regulamentação do salário mínimo, a organização da Justiça do Trabalho, a instituição do ensino profissional e de refeitórios nas indústrias (Leme, 1978: 151). Por exemplo, o decreto que estava sendo discutido sobre 0 salário mínimo só foi anunciado e passou a vigorar a parti de $1^{\circ}$ de maio de 1940 . A Justiça de Trabalho só foi regulamentada a 02 de maio de 1939. Houve ainda a regulamentação da jornada de 08 horas de trabalho diárias e a proibição do trabalho noturno para as mulheres.

A Lei de Férias, o Código do Menor e as Leis sobre Acidente de Trabalho, que vinham da Primeira República sem serem cumpridas, foram regulamentadas em 1934, assim como as comissões mistas de arbitramento e conciliação, já em 1932. Mas não o foram tranquilamente, pois as vantagens dadas aos trabalhadores continuavam a ser contestadas pelos patrões. Os industriais paulistas conseguiram, em novembro de 1932, um retrocesso em relação ao trabalho infantil. A legislação considerava como infantil o menor de 14 anos, mas os patrões conseguiram baixar a idade para 12 anos. Da mesma forma, conseguiram equiparar o teto de trabalho para jovens entre 14 e 18 anos, que fora estabelecido em 6 horas diárias, ao dos adultos, de 8 horas diárias (Leme, 1978). "Apesar dos protestos patronais, entretanto, 0 governo acabou impondo-se e vencendo a resistência dos empresários em aceitar a instituição do salário mínimo" (Leme, 1978: 151). 


\section{A VALORIZAÇÃO DO TRABALHO}

trabalho e do trabalhador da Era Vargas. Desde o início de seu governo, Vargas colocou o trabalhador, a legislação trabalhista e a dignidade (submissa) do trabalho como fundamentais. Vejamos alguns poucos trechos de seus discursos, todas as citações foram retiradas de discursos transcritos em As diretrizes da Nova Política do Brasil

Não é demais repetir que a legislação trabalhista, tal como a entendemos, tem por objetivo dar ao trabalhador de todas as classes um padrão de vida compatível com a dignidade humana e as conquistas sociais e políticas de nosso tempo.

Nenhum governo, nos dias presentes, pode desempenhar a sua função sem satisfazer as justas aspirações das massas trabalhadoras. (...) Ninguém pode viver sem trabalhar; e o operário não pode viver ganhando apenas o indispensável para não morrer de fome.

Além de reconhecer direitos básicos que, naquele contrato (de trabalho - MV) assistem ao trabalhador, a legislação atual visa dar-lhes condições de vida compatíveis com a dignidade humana, elevando-lhes o nível cultural, assegurando-lhe habitação condigna, cuidando da meIhoria de sua alimentação, garantindo-Ihe um salário vital e facultando-Ihe participação efetiva nos negócios públicos, através de organizações sindicais. (Vargas, 1942: 226-227, 229)

Ângela de Castro Gomes, em seu precioso livro $A$ invenção do Trabalhismo, mostra como os trabalhadores tornaram-se figurantes centrais na política pós-30. 0 mais importante, diz Ângela, foi a valorização do trabalho e da dignidade do trabalhador, pois o Estado tentou construir um projeto de identidade operária.

0 valor fundamental do trabalho - como meio de ascensão social e não de saneamento moral - e a dignidade do trabalhador são o eixo em torno do qual se conta sua comunicação com a sociedade e como o mundo da política. 0 estatuto do trabalhador é o que dá identidade social e política ao homem brasileiro, fato magistralmente materializado na carteira de trabalho e pela definiçãa da vadiagem como crime. A cidadania, fundada no gozo dos direitos sociais do trabalhador e no reconhecimento das associações profissionais - ambos tão almejados e demandados pela classe trabalhadora durante décadas - é sancionada com a articulação de um projeto político entre Estado e classe trabalhadora que, ao se efetuar, constrói estes dois atores que assim se conhecem e reconhecem. (Gomes, 2005: 27)

Os ganhos dos trabalhadores não só foram materialmente reais como atenderam às mais caras reivindicações da classe: Vargas falava com frequência sobre o reconhecimento da dignidade do trabalho. Mas houve um preço a pagar: a adesão aos sindicatos controlados pelo Ministério do Trabalho Indústria e Comércio (MTIC). 


\section{ESTADO NOVO}

$\mathrm{O}$

s primeiros cinco anos da década de 1930 foram palco de intensas lutas políticas. A

classe operária e os novos grupos burgueses, assim como os setores médios urbanos, queriam participar das mudanças no poder que ocorriam no período pós-revolucionário e apresentavam suas plataformas, políticas e/ou reivindicativas, propondo diferentes caminhos para alcançar seus objetivos.

No Brasil, o nazifascismo teve inúmeros adeptos na década de 1930. Por todo o país organizavam-se grupos de extrema-direita que se juntaram quase todos na Ação Integralista Brasileira (AIB), fundada a 07 de outubro de 1932, sob a liderança de Plínio Salgado. Os integralistas apoiavam o governo provisório de Getúlio, do qual queriam participar. 0 próprio presidente Vargas demonstrou, naquela época, simpatia pelo fascismo, rejeitando o liberalismo e cercando-se de figuras conhecidas por suas posições de direita, como os generais Góis Monteiro, João Gomes, Pantaleão Pessoa e Eurico Gaspar Dutra, e o sinistro chefe de polícia Filinto Strubing Müller. 0 tempo passava sem a convocação de uma Assembleia Nacional Constituinte que levasse o país de volta à legalidade constitucional.

A revolta paulista de julho de 1932, apesar de fracassada, resultou na convocação da Assembleia Constituinte, e em julho de 1934 a Constituição foi votada e Vargas, eleito, pelo voto indireto, presidente constitucional.

Apesar da adesão da maioria dos trabalhadores à política varguista, anarquistas e comunistas continuaram a lutar pela manutenção das mesmas conquistas, mas com independência de classe, quer dizer, sem a tutela do Ministério do Trabalho. Durante os anos do governo revolucionário, que vão da vitória da Revolução de 1930 à Constituição de 1934, e quase todo 0 ano de 1935, as lutas sociais aumentaram e suas organizações foram criadas e fortalecidas, destacando-se a Aliança Nacional Libertadora [ALN] (28 de março a 11 de julho de 1935). Uma situação que o governo não aceitava. Menos de uma semana depois do lançamento da aliança, a 4 de abril, o governo decretou a Lei de Segurança Nacional. De qualquer maneira, foram anos de intensa movimentação política na sociedade.

Nesse período já são manifestas as intenções de Vargas de angariar o apoio da classe operária submetendo-a às diretrizes do governo, mas o movimento popular representado pela ANL contrapunha-se a esses planos e apoiava as reivindicações operárias, mantendo sua independência de classe. Por isso mesmo a ANL teve seus dias contados, como mostram as provocações do final de junho de 1935 (Vianna, 2011: 173). 0 anticomunismo esperava apenas um pretexto para manifestar-se plenamente e ele foi dado em novembro de 1935, com o chamamento à tomada de quartéis. 
A ANL foi o maior e o mais importante movimento popular do Brasil, arregimentando um sem-número de organizações, e seu fechamento encerrou a etapa mais democrática que o país já viveu. Concordo com a colocação de Tucci Carneiro (1999: 328) de que, com as derrotas da grande frente democrática de 1935, a ANL consolidou-se o autoritarismo no Brasil, cuja base foi o anticomunismo. Vargas já se aproveitara dos levantes de novembro de 1935 para fortalecer seu poder e intensificar a repressão. Antes do Estado Novo, no final de 1935, foram criados a Comissão de Repressão ao Comunismo e, em setembro de 1936, o Tribunal de Segurança Nacional, além da decretação do estado de sítio.

A perseguição não só aos comunistas, mas aos considerados simpatizantes, aos liberais e aos democratas foi brutal, desde o final de 1935. Na segunda metade de 1937, os comunistas que não foram mortos estavam presos ou dispersos e desorganizados. Vargas sabia disso. Seu grande problema eram as eleições, marcadas para março de 1938, que se aproximavam. O paulista Armando de Salles Oliveira, candidato favorito à presidência, estava longe de ser um democrata, mas disputava o poder dentro dos mecanismos liberais constitucionais. 0 problema é que Vargas não estava disposto a deixar o poder e, para manter-se nele, recorreu outra vez ao anticomunismo e aos militares.

Os anos de 1936 e 1937, ainda no período constitucional, foram de extremado anticomunismo. 0 Estado Novo foi, no querer e no dizer do governo, uma "democracia autoritária" que, apesar da brutal repressão ao comunismo e aos liberais progressistas, não perdeu 0 apoio da classe operária. Esta, se teve ganhos (e foram muitos), perdeu, pelo menos temporariamente, sua liberdade.

Nunca será bastante enfatizar o poder das classes dominantes em nosso país, que não admitem conquistas das classes trabalhadoras, por menores que sejam - a não ser que sejam outorgadas por um alto preço e sempre mantidas dentro de limites impostos pelo capitalismo selvagem.

No Brasil, é preciso não confundir nosso chamado liberalismo com democracia. Houve períodos de maior espaço político para manifestações populares, mas estas foram reprimidas conforme se fortaleciam. Foi assim nos primeiros anos 1930 e foi assim no início dos anos 1960.

O liberalismo brasileiro sempre impôs um limite à atuação das classes subalternas e por isso mesmo não vejo como muito esclarecedor opor, "em relação à classe operária", o liberalismo da Primeira República à ditadura varguista. São duas formas de comando das classes dominantes e diferentes formas de a classe operária reagir a esses poderes. Só de maneira estapafúrdia poder-se-ia considerar liberalismo e ditadura como "farinhas do mesmo saco". Não se trata disso. Trata-se de considerar que, dado o tipo de liberalismo existente na Primeira 
República, para as classes subalternas a ditadura implantada por Vargas não trouxe maiores prejuízos, e sim alguns benefícios.

A Constituição de 1891 ignorou os direitos sociais dos trabalhadores. Sem acreditar no liberalismo, sem base teórica sobre o socialismo e sem conhecimento sobre o país, a classe operária se via dividida entre os grupos que diziam representá-la e que brigavam entre si. Quando falamos da importância dos anarquistas na Primeira República e da influência comunista mais tarde, sem que isso deixe de ser verdade, a esmagadora maioria da classe era apática, sem partido e, em termos de arregimentação, os chamados sindicatos amarelos tinham maior número de adeptos.

Vários autores, entre os quais me incluo, e com destaque para o citado livro de Ângela de Castro Gomes, percorreram a formação da classe operária - socialistas, anarquistas e comunistas - e sua busca de identidade como classe, discutindo suas ideologias e propostas de organização. Fica claro, por esses estudos, que, com todas as suas lutas na Primeira República, muitas derrotas, poucas conquistas e feroz repressão, a ditadura varguista não teve para a classe operária o mesmo significado que para as camadas médias urbanas e para os poucos membros das esferas dominantes. Por isso, não creio que ajude manter a discussão sobre se a classe operária aceitou passivamente ou não a cooptação feita por Vargas e as benesses que conseguiu submetendo-se. Em primeiro lugar, é preciso entender qual a visão da classe sobre o liberalismo anterior a 1930 e a ditadura que viria anos depois. A classe operária tinha vivenciado um liberalismo que tratava suas reivindicações como caso de polícia e viu-se diante de uma ditadura que lhe dava direitos e, inclusive, obrigava os patrões a respeitá-los. Por outro lado, não será correto afirmar que a classe operária simplesmente submeteu-se aos ditames do governo. Aceitou os benefícios recebidos, mas não passivamente. As lutas da classe não desapareceram, embora estivessem amortecidas, por algum tempo, pela incrível repressão que se seguiu às insurreições de novembro de 1935 e que tinham se consolidado com o fechamento da ANL e depois com o Estado Novo. E tanto continuou suas lutas, que mal surgiram ares de liberdade, por pouco tempo, no final da guerra, ela reapareceu com suas reivindicações independentes e suas organizações foram se fortalecendo, até o golpe de 1964.

De qualquer maneira, a ditadura getulista seduziu a classe, ao apontar que o liberalismo até então vigente ignorava o social. E a propaganda anticomunista ajudou a afastar os operários do socialismo. Getúlio propôs uma outra via para o capitalismo: a "democracia autoritária", ou uma "ditadura democrática".

0 que considero mais importante na política varguista foi a valorização do trabalho e do trabalhador. A construção positiva da identidade do trabalho no Brasil era muito difícil porque nosso trabalhador não contava, em seu passado, com uma época de liberdade - 
aqui o passado era a escravidão, o trabalho era "coisa de negro". Por isso a valorização do trabalho e a dignificação do trabalhador calaram fundo no movimento operário. A dificuldade da luta que forja a identidade do trabalhador era tão grande, que o líder anarquista Neno Vasco escreveu:

A população brasileira tem ainda como predominantes os elementos incultos, provenientes do trabalho agrícola, de caráter colonial, com ressaibos de escravatura recente; e a esses elementos juntam-se, nos estados de imigração — os do Sul, especialmente - camadas novas e móveis, das quais apenas uma parte se fixa, quase sempre sem se adaptar inteiramente. (...) são, em grande parte, constituídas por trabalhadores rústicos, saídos de regiões atrasadas e miseráveis. Os imigrantes têm, em geral, um escopo único: o amontoamento de um pecúlio para regressar à pátria. (Vasco, 1963: 102-103)

A propalada valorização do trabalhador, mais do que os benefícios recebidos, deu prestígio a Vargas entre os operários, e não foi mero acaso que ele tenha voltado em 1950 eleito elo povo e tenha sido glorificado como "o pai dos pobres".

É verdade, como diz Ângela de Castro Gomes, que,

Vencido o período de reconstitucionalização e dos seus múltiplos ensaios políticos e dimensionada a experiência inicial do Ministério do Trabalho, fechou-se com vigor o espaço para qualquer tentativa de encaminhar o processo de constituição da classe trabalhadora a partir dos próprios trabalhadores. (Gomes, 2005: 30-31)

A valorização do trabalho era cantada em músicas populares. Getúlio afirmava que o fundamental do Estado era garantir os direitos sociais. Já que direitos sociais e paz social eram garantidos, não seriam necessários direitos políticos, como o respeito aos três poderes. Os direitos políticos seriam para reivindicar direitos, mas, uma vez concedidos, estes deixavam de ser necessários.

\section{VIOLÊNCIA E PROPAGANDA}

$\mathrm{F}$ azendo parte da repressão, em um seu aspecto mais disfarçado, o Estado ditatorial promoveu "o controle sistemático das massas, articulado através de um plano orgânico e racional, de cunho nacionalista" (Carneiro, 1999: 333). Queimaram-se livros às centenas, ao mesmo tempo em que se falava da criação de um Brasil moderno e de um novo homem.

As prisões e as torturas não só aniquilaram centenas de militantes democratas como geraram um medo que se entranhava no cotidiano das pessoas - era nisso que o governo apostava para domesticar o povo. Combinada a esse medo, a propaganda manipuladora. 
Além da censura do Departamento de Imprensa e Propaganda, o DIP (dirigido por Lourival Fontes), havia toda a propaganda, típica do nazismo, dirigida à juventude e exaltando-a. Nesse sentido, o incentivo à educação física foi fundamental para as práticas disciplinares. Para isso, muito serviram cerimônias cívicas, sendo criado todo um calendário de comemorações (Parada, 2009). Uma das mais importantes foi a "Parada da Raça", que reunia jovens estudantes desde a escola primária para um desfile civil, pouco antes do 07 de setembro. 0 civismo incentivado nas escolas era uma apologia ao Estado Novo e a Vargas. Eram distribuídos para as crianças livros com a biografia de Vargas, retratado em histórias em quadrinhos como um herói. Vargas era o herói que protegia o povo dos malefícios e do perigo comunista, e isso também justificava o controle policial e a repressão.

Para que se tenha uma pequena ideia do caráter da propaganda, cito o título de alguns artigos da revista do DIP, Estudos e conferências. Alguns números foram inteiramente dedicados à juventude e à importância da educação física, como os de dezembro de 1941 e fevereiro de 1942. Mas a tônica era a louvação a Getúlio Vargas.

\section{"FALTA AlguÉm EM NUREMbERG"}

$\mathrm{E}^{\mathrm{s}}$ ste é o título do livro em que o repórter David Nasser (1966) narra as torturas cometidas pela polícia de Filinto Müller e que eram de pleno conhecimento de Getúlio Vargas. Segundo Elizabeth Cancelli, o aparelho policial do governo Vargas vinha sendo cuidadosamente montado desde 1933 (Cancelli, 1993: 50), sendo que já em 1931 Batista Luzardo trouxera técnicos policiais de Nova York "para organizar o serviço de combate ao comunismo da polícia do Distrito Federal" (Cancelli, 1993: 83). E logo depois da derrota das insurreições de novembro de 1935 começaram as negociações para efetivar a colaboração entre a polícia brasileira e a Gestapo (Cancelli, 1993: 87), o que não impediu que membros da famigerada polícia nazista estivessem presentes na prisão de Harry Berger e começassem a torturá-lo ainda no carro que o levava à prisão - e à loucura.

0 delegado especial de Polícia, capitão Afonso Henrique Miranda Correa, recebeu de Heinrich Himmler, líder da SS e chefe de Polícia do III Reich, um dos maiores criminosos de guerra nazistas, a ordem de Primeira Classe da Cruz Vermelha (Cancelli, 1993: 90).

A entrega de Olga Benário, grávida de sete meses, aos nazistas, para ser assassinada, foi de responsabilidade de Vargas, de Filinto Müller e também e principalmente da última instância a que se recorreu para evitar sua extradição, os ministros do Superior Tribunal Federal. Dos onze ministros, apenas três votaram contra a entrega de Olga à Gestapo: Carlos Maximiliano, Eduardo Espínola e Carvalho Mourão.' 


\section{CONCLUSÃO}

$\mathrm{O}$

autoritarismo não era novidade em nossa sociedade. Passamos 400 anos tratando ou-

tros seres humanos como se fossem bichos (semoventes). Uma sociedade desde sempre discriminadora, elitista e, consequentemente, altamente repressora. Os exemplos disso são inúmeros e seria longo citá-los. Depois da escravidão, a classe operária foi tratada como grupo inferior: os pés e os braços que serviam ao cérebro (ou que eram comandados pelo cérebro) - a elite no poder. As tentativas não só de subverter a ordem vigente, mas de conseguir melhorias no nível de vida e nas condições de trabalho foram sempre brutalmente reprimidas. O Estado Novo, conseguindo o apoio submisso da classe operária e controlando a desmedida exploração dos trabalhadores, consolidou maneiras de pensar e de atuar dos donos do poder, agora cooptando boa parte das classes subalternas para a aceitação da ideologia dominante. E os grupos democráticos que tentavam mudar a situação não foram capazes de criar uma contraideologia que chegasse ao coração das massas.

A repressão e a propaganda fizeram com que qualquer manifestação contrária ao governo, qualquer crítica ao presidente-ditador fosse considerada solerte trama comunista, de traidores da pátria a serviço de Moscou. A propaganda anticomunista se mantém até hoje como fio condutor de todos os reacionários.

O que pretendo enfatizar é o fato de que a discussão condenando os operários como se tivessem se submetido sem mais à política varguista ou, ao contrário, como se tivessem se oposto valentemente a ela é uma discussão que não nos ajuda a avançar. É preciso perguntar quem eram esses operários, qual sua situação de vida, como foram tratados na Primeira República, o que realmente perderam, o que realmente ganharam com a política trabalhista de Vargas. Ganharam muito, sem dúvida, e muitos aceitaram Vargas como pai protetor, sem críticas, só com agradecimentos. Não perderam tanto, uma vez que, mesmo dentro dos sindicatos governamentais, continuaram lutando por sua independência. De qualquer forma, a discussão quase sempre gira em torno da aceitação ou não de vantagens materiais conseguidas. Ângela de Castro Gomes ressalta o poder do falado reconhecimento da dignidade individual e profissional do operário e de seu reconhecimento como ator político. Cabem aqui as palavras de E. P. Thompson, sobre as discussões em torno do reconhecimento apenas de necessidades econômicas, o que considera, "em última instância, uma definição capitalista da necessidade humana" (Thompson, 2000: 11).

Esta definição da necessidade, em termos materiais econômicos, tende a impor uma hierarquização que privilegia insuficientemente outras necessidades: as necessidades de identidade, as 
necessidades de identidade de gênero, as necessidades de respeito e posição social entre os próprios trabalhadores. (Thompson, 2000: 11-12)

Thompson enfatiza ainda a necessidade de se levar em conta não só as relações de poder como "encontrar as razões da sem-razão social" (Thompson, 2000: 12). Acho que isso ainda nos falta para entender o apoio da grande maioria dos operários ao ditador Getúlio Vargas. Entender essa "sem razão" nos ajudaria a compreender, hoje, embora em um cenário histórico bastante diferente, a atitude de inúmeros trabalhadores ou, simplesmente, do chamado "povão".

Vargas foi deposto a 29 de outubro de 1945. Se por um lado era difícil manter o Estado Novo depois da participação do Brasil na guerra em defesa da democracia, o ambiente de distensão política e de práticas democráticas durou pouco. 0 discurso de Winston Churchill em 5 de março de 1946, em Fulton (quando cunhou o termo "cortina de ferro"), deu início à Guerra Fria e em pouco tempo o partido comunista - que havia obtido quase $10 \%$ da votação nacional nas eleições de dezembro de 1945 - foi colocado fora da lei, tendo, em maio de 1947, seus parlamentares os mandatos cassados.

A utilização da propaganda anticomunista foi — é — tão forte, que nem o governo JK, considerado um "oásis de democracia", nem o de Jango foram capazes de legalizar o PCB. O golpe militar de 1964 utilizou a mesma surrada propaganda anticomunista, solidificada nos anos 1930 e com o Estado Novo.

A legislação trabalhista varguista, atrelando o movimento operário e sindical ao Ministério do Trabalho, com tudo que se possa criticar nela, está sendo desmontada hoje pelos donos do poder agroindustrial. Temos, hoje, o país com as maiores diferenças sociais. Em nenhum outro lugar do mundo a distância entre pobres e ricos é tão grande. Talvez essa seja a maior discriminação repressora de nossa sociedade "liberal-democrática". Para isso contribuíram a eficácia da propaganda e a manipulação do anticomunismo durante o Estado Novo, que banalizou as práticas violentas e desumanas de que padecemos até hoje.

A tragédia da pandemia que assola o mundo na hora atual - e brutalmente o Brasil — mostra as absurdas diferenças sociais do país, com mais de 40 milhões de pessoas necessitando dos 600 reais mensais para sustentar suas famílias.

\section{NOTA}

1 Votaram pela entrega de Olga aos nazistas: Bento de Faria, que foi o relator, Plínio Casado, Edmundo Lins, Hermenegildo de Barros, Laudo de Camargo, Costa Manso, Octávio Kelly e Ataulpho de Paiva. 


\section{REFERÊNCIAS BIBLIOGRÁFICAS}

CANCELLI, E. Mundo da violência — a polícia da era Vargas. Brasília: Ed. UNB, 1993.

CARNEIRO, M. L. T. O Estado Novo, o DOPS e a ideologia da segurança nacional. In: PANDOLFI, D. (org.). Repensando o Estado Novo. Rio de Janeiro: FGV, 1999.

CENTRO SOCIALISTA DE SANTOS. A questão social, n. 1, p. 1, 1895.

GOMES, A. C. A invenção do trabalhismo. 3. ed. Rio de Janeiro: FGV, 2005.

LEME, M. S. A ideologia dos industriais brasileiros (1919-1945). Petrópolis: Vozes, 1978. (Coleção História Brasileira $\left.n^{\circ} 2\right)$.

LEUENROTH, E. Anarquismo, roteiro da libertação social. Rio de Janeiro: Mundo Livre, 1963.

NASSER, D. Falta alguém em Nuremberg. Torturas da Polícia de Filinto Strubling Müller. 4. ed. Rio de Janeiro: Edições 0 Cruzeiro, 1966.

PANDOLFI, D. (org.). Repensando o Estado Novo. Rio de Janeiro: FGV, 1996.

PARADA, M. Educando corpos e criando a nação: cerimônias cívicas e práticas disciplinares no Estado Novo. Rio de Janeiro: Apicuri, 2009.

PARTIDO COMUNISTA DO BRASIL. Movimento Comunista. Editorial, nº 1, jan. 1922.

PARTIDO SOCIALISTA BRASILEIRO. Programa do Partido Socialista Brasileiro. O Estado de São Paulo, 28 ago. 1902.

PEREIRA, A. Silvério Fontes, pioneiro do marxismo no Brasil. Revista Estudos Sociais, v. 3, n. 12, 1962.

PEREIRA, A. Formação do PCB, 1922-1928. Lisboa: Prelo, 1976.

PICCAROLO, A. O socialismo no Brasil, esboço de um programa de ação socialista. São Paulo: Piratininga, 1932.

SAMIS, A. Clevelândia: Anarquismo, sindicalismo e repressão política no Brasil. Rio de Janeiro: Achiamé; São Paulo: Imaginário, 2002.

SIMÃO, A. Sindicato e Estado. São Paulo: Dominus Editora, 1966.

THOMPSON, E. P. Agenda para una história radical. Barcelona: Crítica, 2000.

VARGAS, G. As diretrizes da Nova Política do Brasil. Rio de Janeiro: José Olympio, 1942.

VASCO, N. Origens e primórdios de atividade. In: LEUENROTH, E. Anarquismo, roteiro de libertação social. Rio de Janeiro: Mundo Livre, 1963. p. 102-103xx.

VASCO, N. A concepção anarquista do sindicalismo. 2. ed. Lisboa: Afrontamento, 1984.

VIANNA, M. A. G. Revolucionários de 1935 - sonho e realidade. 3. ed. São Paulo: Expressão Popular, 2011.

VIANNA, O. Problemas de organização e problemas de direção. Rio de Janeiro: José Olympio Editora, 1952. 